\title{
PENINGKATAN PENGETAHUAN REMAJA TENTANG DAMPAK POSITIF DAN NEGATIF PENGGUNAAN MEDIA SOSIAL TERHADAP KESEHATAN FISIK DAN MENTAL DENGAN PENDEKATAN PEER GROUP DI SMPN 21 PEKANBARU
}

\author{
Tesha Hestyana Sari'), Wiwiek Delvira' ${ }^{2)}$, Dira Wirdaniza ${ }^{3)}$, Sindy Shalsabella \\ Ashali $^{4)}$ \\ 1,2,3,4) Poltekkes Kemenkes Riau \\ Email: tesha@pkr.ac.id
}

\begin{abstract}
ABSTRAK
Perkembangan media sosial dengan berbagai fitur yang dapat diakses dimanapun membuat semakin banyak pengguna media sosial dari berbagai kalangan seperti remaja. Penggunaan media sosial dengan berbagai dampaknya perlu disosialisasikan kepada remaja karena saat ini media sosial memiliki dampak positif dan negatif terhadap kesehatan fisik dan mental. Tujuan umum dari kegiatan pengabdian kepada masyarakat ini adalah untuk mengetahui gambaran pengetahuan remaja tentang dampak positif dan negatif penggunaan media sosial bagi kesehatan jiwa. Metode dalam kegiatan pengabdian masyarakat ini adalah pendidikan kesehatan dengan pendekatan peer group. Hasil kegiatan ini didaptkan pre-test dan post-test, terjadi peningkatan pengetahuan dengan nilai rata-rata pre-test 78,6 dan post-test 96,6 . Perbedaan peningkatan nilai ratarata yaitu sebesar 18,1 . Hasil uji statistik didapatkan nilai $0,000(\mathrm{p}<0,05)$ yang dapat disimpulkan ada perbedaan yang signifikan antara pre-test dan post-test yang dilakukan oleh para siswa di SMPN 21 Pekanbaru. Saran untuk pihak sekolah adalah untuk memasukkan kegiatan peningkatan pengetahuan remaja tentang media sosial, dampak positif serta dampak negatif dari penggunaan media sosial ke dalam jadwal ekstrakulikuler sekolah. Hal ini dapat dilakukan dalam kelompok-kelompok/ peer group bersama duta media sosial yang telah dipilih.
\end{abstract}

Kata kunci: Media sosial, Remaja, Pengetahuan

\section{ABSTRACT}

The growth of social media with various features that can be accessed anywhere makes social media users increase from sorts of backgrounds among teenagers. The use of social media with several impacts needs to socialize to teenagers due to current social media has positive and negative impacts on physical and mental health. The general objective of this community service activity is to find out the description of adolescent knowledge about the positive and negative impacts of using social media for mental health. The method in this community service activity is health education with a peer group approach. The results of this activity obtained pre-test and post-test, an increase in knowledge with an average value of 78.6 pre-tests and 96.6 post-test. The difference in increase of average values is 18.1. Statistical test results obtained a value of 0,000 ( $p$ $<0.05)$, which can conclude that there is a significant difference between pre-test and post-test conducted by students at SMPN 21 Pekanbaru. Suggestions for schools are to include activities for improving adolescent knowledge about social media, the positive and negative impacts of using social media in the school extracurricular schedule. It can be done in groups/peer groups with selected social media ambassadors.

Keywords: Social media, Teenagers, Knowledge 


\section{PENDAHULUAN}

Saat ini perkembangan teknologi semakin berkembang seperti semakin banyaknya media sosial. Media sosial merupakan sekelompok aplikasi yang menggunakan basis internet serta penggunaan teknologi web yang di dalammnya terdapat penciptaan atau pertukaran informasi oleh penggunanya (Kaplan \& Haenlein, 2010). Beberapa media sosial yang banyak digunakan saat ini yaitu Facebook, Twitter, Whatsapp, Tik-tok, Instagram, Line, Brainly dan Google+ (O'Keefe \& Clarke, 2011; We Are Social, 2016; Atila, 2018).

Perkembangan media sosial dengan berbagai fitur yang dapat diakses dimanapun membuat semakin banyak pengguna media sosial dari berbagai kalangan. Di Indonesia jumlah pengguna media sosial aktif pada tahun 2015 adalah 79 juta (We Are Social, 2015). Sementara itu pada tahun 2016 terdata pengguna media sosial sebanyak 129, 2 juta $(97,4 \%)$ (APJII, 2016).

Media sosial memiliki dampak positif dan juga dampak negatif. Berdasarkan hasil penelitian oleh Wijaya \& Godwin (2012), beberapa dampak positif dari penggunaan media sosial seperti memberikan pengaruh pada kehidupan dunia nyata pada remaja secara prososial dan juga antisosial. Secara prososial, media sosial menjadi media pertemanan, sarana pertukaran informasi, memperluas wawasan serta berbisnis online yang dapat memberikan keuntungan materi. Selanjutnya secara antisosial, media sosial dapat menimbulan pertengkaran di media sosial, penyebarluasan foto-foto yang tidak pantas, status-status yang tidak membangun dan lain sebagainya.

McDool et al (2016 dalam Sari et al, 2018) menyebutkan bahwa satu jam saja remaja menggunakan media sosial dalam sehari akan mengakibatkan kerugian karena adanya cyberbullying, penurunan aktivitas tatap muka serta peningkatan terjadinya perbandingan sosial. Remaja cenderung terpengaruh serta mudah percaya terhadap isi media sosial dan akan mempengaruhi konsep diri remaja. Hasil penelitian lainnya oleh Tartari (2015) di Albania, dampak positif dari penggunaan media sosial oleh remaja adalah meningkatkan interaksi berkomunikasi, mendapatkan informasi dan mengembangkan kemampuan penggunaan teknologi. Hasil penelitian ini juga memperlihatkan dampak negatif penggunaan media sosial yaitu remaja memiliki risiko depresi Facebook, cyberbullying dan juga dapat mengakibatkan terjadinya pelecehan seksual secara online.

Masa remaja saat ini dengan penggunaan media sosialnya sangat perlu diperhatikan. Masa remaja merupakan masa transisi yang ditandai dengan perubahan fisik, emosi serta psikis. Masa remaja adalah periode peralihan dari masa anak ke masa dewasa (Widyastuti dkk, 2009).

Monks (2004) membagi kelompok remaja menjadi tiga yaitu remaja awal dengan rentang usia 12 sampai dengan 15 tahun, remaja pertengahan yaitu rentang usia 15-18 tahun, dan remaja akhir dengan rentang usai 18 sampai dengan 21 tahun. Masa remaja ini merupakan masa yang sangat penting dimana adanya peralihan dari masa kanakkanak menjadi masa dewasa yang terjadi berbagai perubahan seperti perubahan fisik, seksual, psikologis maupun mental. Adanya perubahan-perubahan ini maka perlu diperhatikan karena akan mengakibatkan respon berbeda pada diri remaja.

Penggunaan media sosial dengan berbagai dampaknya perlu disosialisasikan kepada remaja. Hal ini dikarenakan hampir sebagian besar remaja menggunakan media sosial lebih dari 1 dari smartphone yang dimiliki serta penggunaan yang terus-menerus. Media sosial memberikan ruang kebebasan bagi remaja untuk mengekspresikan dirinya. Berbagai kegiatan sehari-hari yang dilakukan oleh remaja baik itu menampilkan kebahagiaan ataupu kesedihan yang dirasakan. Hal ini akan juga mempengaruhi konsep 
diri remaja. Oleh sebab itu, salah satu bentuk informasi yang diberikan adalah berupa pengetahuan terkait dampak penggunaan media sosial.

Menurut Adlany (2010) pengetahuan (knowledge) adalah sesuatu yang hadir dan terwujud dalam jiwa dan pikiran seseorang dikarenakan adanya reaksi, persentuhan, dan hubungan dengan lingkungan dan alam sekitarnya. Maka dapat disimpulkan bahwa pengetahuan merupakan informasi yang diketahui atau disadari oleh seseorang. Pengetahuan dapat diperoleh melalui berbagai sumber. Berdasarkan penelitian oleh Wawan (2009) menyebutkan bahwa hal yang mempengaruhi tinggi rendahnya pengetahuan antara lain lingkungan, pendidikan, teman sebaya, media massa, sosial budaya, ekonomi, dan pengalaman.

Pekanbaru merupakan salah satu kota yang cukup berkembang. Data jumlah penduduk pekanbaru pada tahun 201 adalah 1.038.118 jiwa (BPS, 2017). Sementara itu usia anak dan remaja rentang usia 10-19 tahun adalah 186.202 jiwa. Berdasarkan data tersebut terlihat bahwa perkembangan jumlah remaja akan menigkat. Maka dari itu perlu perhatian terhadap kesehatan fisik dan mental disamping perkembangan teknologi yang semakin maju. Salah satu upaya preventif dan promotif yang dapat dilakukan adalah melalui peningkatan pengetahuan secara langsung kepada remaja yang dapat dilakukan di sekolah dengan metode pendidikan kesehatan oleh pendidik serta pendidikan kesehatan dengan pendekatan peer group.

Salah satu sekolah menengah pertama dengan jumlah siswa yang cukup banyak terdapat di SMPN 21 Pekanbaru. Lokasi sekolah ini terletak di Jl. Soekarno Hatta No.639 kelurahan Sidomulyo Timur, kecamatan Marpoyan Damai Kota Pekanbaru. Lokasi ini memperlihatkan siswa berada di kawasan yang cukup ramai. Siswa dapat berjumpa dengan berbagai kalangan karena berada dekat di salah satu pusat pasar dan di juga dekat dengan per-empatan jalan. Lokasi seperti ini dapat mempermudah akses para siswa untuk melakukan kegiatan dan bertemu dengan banyak orang.

Disamping lokasi sekolah yang dekat dengan keramaian, sekolah ini juga memberikan kebebasan pada siswa untuk menggunakan handphone di dalam lingkungan sekolah dengan waktu yang tidak terbatas. Hasil studi pendahuluan dari 8 orang siswa SMPN 21, 8 (100\%) mengatakan belum pernah mendapatkan informasi di sekolahnya tentang pendidikan kesehatan dengan materi media sosial dan penggunaannya. Selain itu, hasil wawancara dengan pihak sekolah, sekolah juga belum memiliki kegiatan tambahan terkait sosialisasi penggunaan media sosial. Selain itu, dari hasil wawancara dengan 8 orang siswa, seluruhnya memiliki handphone dengan tipe android dan memiliki lebih dari 2 media sosial seperti facebook, instagram, tik-tok, youtube. Berdasarkan kondisi ini, maka perlu kegiatan promotif sekaligus preventif terutama yang ditujukan kepada para remaja yang masih tergolong sangat muda. Hal ini juga mengingat bahwa usia para remaja ini rentan dengan pemahaman informasi elektronik yang belum matang atau mudah terpengaruh dari penggunaan teknologi yang dapat berdampak positif ataupun negatif pada kesehatan fisik dan mental remaja.

Adapun tujuan umum dari kegiatan pengabdian kepada masyarakat ini adalah untuk mengetahui gambaran pengetahuan remaja tentang dampak positif dan negatif penggunaan media sosial bagi kesehatan jiwa. Sementara itu tujuan khususnya adalah memberikan pengetahuan tentang jenis-jenis media sosial dan kegunaannya, memberikan pengetahuan tentang dampak positif penggunaan media sosial, memberikan pengetahuan tentang dampak negatif penggunaan media sosial dan meningkatkan pengetahuan remaja tentang kiat menghindari dampak negatif penggunaan media sosial bagi kesehatan fisik dan mental. 


\section{TINJAUAN PUSTAKA}

\section{Pengetahuan}

Dalam dalam kamus filsafat, pengetahuan adalah proses kehidupan yang diketahui manusia secara langsung dari kesadarannya sendiri. Dalam peristiwa ini, yang mengetahui (subjek) memiliki yang diketahui (objek) di dalam dirinya sendiri sedemikian aktif sehingga yang mengetahui itu menyusun yang diketahui pada dirinya sendiri dalam kesatuan aktif (Bakhtiar, 2004).

Menurut Adlany (2010) pengetahuan (knowledge) adalah sesuatu yang hadir dan terwujud dalam jiwa dan pikiran seseorang dikarenakan adanya reaksi, persentuhan, dan hubungan dengan lingkungan dan alam sekitarnya. Maka dapat disimpulkan bahwa pengetahuan merupakan informasi yang diketahui atau disadari oleh seseorang.

\section{a. Tingkat Pengetahuan}

Pengetahuan seseorang tarhadap objek mempunyai intensitas atau tingkatan yang berbeda-beda. Menurut Notoatmodjo (2010) tingkat pengetahuan secara garis besarnya dibagi dalam 6 tingkat :

1) Tahu (know)

Tahu diartikan hanya sebagai recall (memanggil) memori yang telah ada sebelumnya setelah mengamati sesuatu. Tahu ini merupakan tingkat pengetahuan yang paling rendah. Kata kerja untuk mengukur bahwa orang tahu tetang apa yang dipelajari antara lain : menyebutkan, menguraikan, mendefenisikan, menyatakan, dan sebagainya

2) Memahami (comprehension)

Memahami suatu objek bukan sekedar tahu terhadap objek tersebut, tidak sekedar menyebutkan, tetapi orang tersebut harus dapat menginterpretasikan secara benar tentang objek yang diketahui tersebut.

3) Aplikasi (application)

Aplikasi diartikan apabila seseorang yang telah memahami objek yang dimaksud dapat menggunakan atau mengaplikasikan prinsip yang telah diketahui tersebut pada situasi yang lain.

4) Analisis (analysis)

Analisis adalah kemampuan seseorang untuk menjabarkan dan memisahkan dan mencari hubungan antara komponene yang terdapat dalam suatu masalah atau objek yang diketahui. Indikasi bahwa pengetahuan seseorang telah sampai pada tingkat analisis adalah apabila seseorang tersebut telah dapat membedakan atau mengelompokkan, membuat diagram (bagan) terhadap pengetahuan atas objek tersebut.

5) Sintesis (synthesis)

Sintesis menunjukkan kepada suatu kemampuan seseorang untuk merangkum atau meletakkan dalam satu hubungan yang logis dari komponen-komponen pengetahuan yang dimiliki. Dengan kata lain sintesis adalah suatu kemampuan untuk menyusun formulasi baru dari formulasi-formulasi yang telah ada.

6) Evaluasi (evaluation)

Evaluasi ini berkaitan dengan kemampuan seseorang untuk melakukan justifikasi atau penilaian terhadap suatu objek tertentu. Penilaian ini dengan sendirinya didasarkan pada suatu kriteria yang ditentukan sendiri.

\section{b. Faktor-faktor yang mempengaruhi pengetahuan}

Adapun beberapa faktor yang mempengaruhi pengetahuan menurut Notoatmodjo (2010) yaitu : 


\section{1) Umur}

Bertambahnya umur seseorang dapat berpengaruh pada pertambahan pengetahuan yang diperolehnya, akan tetapi pada umur-umur tertentu atau menjelang usia lanjut kemampuan penerimaan atau mengingat suatu pengetahuan akan berkurang.

2) Intelegensi

Intelegensi diartikan sebagai suatu kemampuan untuk belajar dan berfikir abstrak guna menyesuaikan diri secara mental dalam situasi baru. Intelegensi merupakan salah satu faktor yang mempengaruhi hasil dari proses belajar. Intelegensi bagi seseorang merupakan salah satu modal untuk berfikir dan mengolah berbagai informasi secara terarah sehingga ia mampu menguasai lingkungan . Dengan demikian dapat disimpulkan bahwa perbedaan intelegensi dari seseorang akan berpengaruh pula terhadap tingkat pengetahuan.

\section{3) Lingkungan}

Lingkungan merupakan salah satu faktor yang mempengaruhi pengetahuan seseorang. Lingkungan memberikan pengaruh pertama bagi seseorang, dimana seseorang dapat mempelajari hal-hal yang baik dan juga hal-hal yang buruk tergantung pada sifat kelompoknya. Dalam lingkungan seseorang akan memperoleh pengalaman yang akan berpengaruh pada pada cara berfikir seseorang.

\section{4) Sosial budaya}

Sosial budaya mempunyai pengaruh pada pengetahuan seseorang. Seseorang memperoleh suatu kebudayaan dalam hubunganya dengan orang lain, karena hubungan ini seseorang mengalami suatu proses belajar dan memperoleh suatu pengetahuan.

5) Pendidikan

Pada umumnya semakin tinggi pendidikan seseorang semakin baik pula pengetahuannya.

6) Informasi

Informasi akan memberikan pengaruh pada pengetahuan seseorang. Meskipun seseorang memiliki pendidikan yang rendah tetapi jika ia mendapatkan informasi yang baik dari berbagai media misalnya tv, radio atau surat kabar maka hal itu akan dapat meningkatkan pengetahuan seseorang.

7) Pengalaman

Pengalaman merupakan guru yang terbaik. Pepatah tersebut dapat diartikan bahwa pengalaman merupakan sumber pengetahuan, atau pengalaman itu suatu cara untuk memperoleh kebenaran pengetahuan. Oleh sebab itu pengalaman pribadi pun dapat digunakan sebagai upaya untuk memperoleh pengetahuan. Hal ini dilakukan dengan cara mengulang kembali pengalaman yang diperoleh dalam memecahkan permasalahan yang dihadapi pada masa lalu.

\section{Media sosial dan dampaknya terhadap kesehatan fisik dan mental}

Media sosial saat ini telah berkembang pesat. Banyak jenis media sosial yang diciptakan seperti twitter, path, linkdin, instagram, facebook dan yang lainnya. Media sosial merupakan kelompok aplikasi dengan basis internet dan teknologi web yang dapat menciptakan dan pertukaran konten oleh penggunanya (Kaplan \& 
Haenlein, 2010). Menurut Carlsson (2010), dalam media sosial terjadi interaksi sosial yang memungkinkan penggunanya dapat memberikan pendapat, ide serta pengetahuan di dalam forum secara global dengan waktu dan tempat yang tidak signifikan. Begitu juga dengan media sosial facebook, biasanya digunakan penggunanya untuk membuat profil, mengirimkan foto atau video, membuat status terbaru, berkomunikasi dengan teman serta keluarga dan tempat mendiskusikan sesuatu (Ooeldorf-Hirsch \& Sundar, 2015; Shen, Brdiczka \& Liu, 2015).

Media sosial memiliki dampak positif dan juga negatif pada penggunanya. Menurut penelitian oleh Tartari (2009) yang dilakukan di albania dengan wawancara kepada remaja yang berusia 11-16 tahun dimana sering menggunakan media sosial, terlihat bahwa hal positif yang mereka dapatkan dari menggunakan media sosial adalah meningkatkan mereka dalam kemampuan komunikasi, mendapatkan informasi, dan mengembangkan keterampilan dalam penggunaan tekologi. Di samping itu, hal negatif yang terlihat dalam hasil penelitian ini adalah remaja memiliki risiko terkena depresi facebook, cyberbullying serta pelecehan seksual secara online.

Penelitian lainnya oleh Okoiye et al (2015) yang dilakukan di nigeria pada 300 remaja, didapatkan hasil bahwa harga diri, konsep diri, self eficacy memiliki hubungan yang signifikan dengan cyberbullying remaja di sekolah. Penelitian ini merekemomendasikan bahwa remaja harus diberikan pendidikan moral di sekolah sehingga memiliki karakter yang baik dan memiliki kemampuan dalam menjalin hubungan yang positif dengan orang lain serta mengawasi remaja dalam menggunakan internet untuk membantu mereka mengekspresikan perilaku yang baik dalam hubungan interpersonal dengan teman-temannya.

Penggunaan media sosial yang berlebihan dapat menyebabkan kecanduan bagi penggunanya. Ciri-ciri kecanduan media sosial yang diungkap menurut teori goldberg yaitu; sering lupa waktu, gejala menarik diri, muncul sebuah kebutuhan konstan untuk meningkatkan waktu yang dihabiskan, kebutuhan peralatan komputer dan aplikasi yang lebih baik/lebih banyak, sering berkomentar, berbohong, prestasi rendah, menutup diri secara sosial dan kelelahan (nurmandia, 2013).

\section{Remaja}

Masa remaja merupakan masa perkembangan transisi antara masa anak dan masa dewasa yang meliputi perubahan biologis, kognitif dan sosial emosional (Santrock, 2008). Masa remaja dimulai dari usia 10 sampai 13 tahun dan berakhir pada usia 18 sampai 20 tahun (Santrock, 2008). Sementara itu, Steinberg (2011) menyatakan masa remaja adalah masa dengan rentang usia 11-21 tahun.

Masa remaja dipandang sebagai tahap utama dalam pembangunan manusia karena mulai dalam penentuan bahwa siapa ia, apa serta ingin menjadi siapa ketika di masa depan (Erikson, 1968 dalam Papalia et.al, 2011). Disamping itu, Hurlock (2011) menyebutkan masa remaja terdiri dari beberapa fase seperti fase pencarian jati diri, fase penuh konflik, fase yang penuh penentangan dan disertai perubahan atau transisi dengan berbagai tingkat stres dimana memiliki dampak pada perkembangan psikologis remaja. Stanley hall (dalam Santrock, 2008) menyatakan bahwa masa remaja seperti masa topan badai dan stres (storm \& stress) dimana remaja memiliki keinginan yang bebas dalam menentukan nasib dirinya.

Masa remaja juga dikatakan sebagai masa yang tidak realistik (Hurlock, 2011). Arti dari kalimat ini adalah remaja cenderung melihat dirinya dan orang lain 
sebagaimana dari hal yang ia inginkan, bukan karena apa yang ada sebenarnya. Remaja akan mengalami kekecewaan jika orang lain mengecewakan atau dirinya tidak mampu memenuhi tujuan yang telah ditetapkannya. Bertambahnya pengalaman pribadi dan pengalaman sosial serta peningkatan kemampuan rasional, akan menjadikan remaja semakin dapat memandang dirinya, keluarga, teman serta lingkungannya dengan lebih realistik (Hurlock, 2011).

\section{Pendidikan Kesehatan dengan Pendekatan Peer Group (Kelompok Sebaya)}

Pendidikan kesehatan adalah proses untuk mengubah perilaku manusia yang meliputi pengetahuan, sikap, atau perbuatan yang berhubungan dengan tujuan hidup sehat baik secara individu atau pun kelompok (Triwibowo dan Puspahandani, 2015). Beberapa metode yang dapat digunakan dalam pendidikan kesehatan yaitu ceramah, diskusi kelompok, curhat pendapat, demonstrasi, dan seminar. Pemberian pendidikan kesehatan dapat menggunakan berbagai metode yang sesuai dengan tujuan spesifik yang ingin dicapai (pengetahuan, sikap atau praktik partisipan) (Nursalam dan Efendi, 2008). Adapun penjelasan singkat tentang metode pendidikan kesehatan adalah sebagai berikut:

a) Ceramah

Menurut Notoatmodjo (2010), metode ceramah efektif dan efisien untuk sasaran dalam jumlah banyak. Metode ceramah dapat dilengkapi menggunakan audiovisual, tanya jawab dan demonstrasi yang bertujuan agar ceramah dapat lebih menarik (Afandi, Chamalah, \& Wardani, 2013). Kelebihannya adalah dapat meningkatkan ingatan antara 40\%-60\% dengan menggunakan alat bantu visual dan memberikan gambaran untuk menuntun seseorang mengambil tindakan dan menghemat waktu. Kekurangannya adalah partisipasi peserta pasif dan cepat membosankan jika ceramahnya kurang menarik.

b) Diskusi kelompok

Metode diskusi kelompok adalah seperti dibentuknya kelompok-kelompok kecil dan dituntut untuk menyelesaikan suatu kasus atau masalah. Kelebihan metode ini adalah para peserta dapat mengekspresikan kemampuan dan bersaing secara sehat secara objektif. Sementara itu kelemahannya yaitu apabila petunjuk pelaksanaan tugas kurang jelas, hasil kerja peserta akan menyimpang dari tujuan instruksional yang diharapkan dan membutuhkan waktu yang lama dalam penyelesaian masalah.

c) Curah pendapat

Metode ini diawali dengan adanya sebuah kasus/masalah dan kemudian memberikan kesempatan masing-masing peserta untuk memberikan pendapatnya. Kemudian akan terjadi diskusi dalam prosesnya. Adapun kelebihan metode ini adalah dapat memperoleh sejumlah pendapat dan pandangan yang lebih obyektif, sedangkan kekurangannya adalah sulit menganalisis dan kurang memperoleh pemikiran yang bulat.

d) Seminar

Seminar merupakan suatu metode dimana dalam kegiatannya berupa pertemuan yang dihadiri 5 atau lebih orang dengan bimbingan orang yang menguasai bidang tertentu dalam menyelesaikan atau membahas suatu topik. Kelebihan metode ini adalah menyajikan bahan-bahan serta keterangan baru dan dapat mempelajari topik-topik secara mendalam. Kekurangan metode ini adalah jika peserta memberikan banyak pertanyaan, akan sulit bagi pembicara menjawab pertanyaan karena keterbatasan waktu. 


\section{e) Demonstrasi}

Demonstrasi adalah suatu penyajian untuk memperlihatkan suatu tindakan, adegan, atau memperlihatkan prosedur tertentu. Kelebihan metode ini adalah dapat memberikan ketrampilan tertentu dan memudahkan sasaran memahami jelas suatu prosedur. Adapun kekurangannya adalah jika waktu yang disediakan terbatas akan menyulitkan sasaran mempraktekkan demonstrasi. Pendidikan kesehatan dapat dilakukan dengan pendekatan peer group atau kelompok sebaya pada remaja. Kelompok sebaya atau peer group adalah suatu proses komunikasi, informasi dan edukasi yang dilakukan oleh dan untuk kalangan sebaya. Kalangan satu kelompok, dapat berarti satu kelompok sebaya pelajar, kelompok mahasiswa, sesama rekan kerja, sesama profesi dan jenis kelamin (Lufhiani, 2011).

Kelompok sebaya dapat memberikan pengaruh yang besar sehingga remaja berusaha untuk meniru teman sebayanya. Hal tersebut dapat terjadi karena remaja lebih banyak menghabiskan waktu dengan teman sebayanya daripada masa pertengahan atau kanak-kanak akhir. Karena remaja lebih banyak berada di luar rumah bersama dengan teman-teman sebagai kelompok sebaya, maka dapatlah dimengerti bahwa pengaruh teman sebaya pada sikap, pembicaraan, minat, penampilan, perilaku, pengetahuan lebih besar dari pada pengaruh keluarga (Hurlock, 2008).

Selanjutnya, menurut Rozak (2006) penyesuaian diri remaja kepada kelompok sebayanya adalah usaha remaja untuk berada dalam lingkungan sosial yang lebih luas. Pergerakan remaja menuju kelompok sebayanya adalah salah satu tugas perkembangan remaja. Perkembangan sosial remaja dapat dilihat dengan adanya dua macam gerak yaitu memisahkan diri dari orang tua dan menuju kearah teman-teman sebaya. Remaja dalam kehidupan sosialnya lebih tertarik dengan kelompok sebayanya sehingga apa yang dilakukan kelompok sebaya kemungkinan akan ditiru oleh remaja (Rozak, 2006).

\section{METODE PELAKSANAAN}

Kegiatan pengabdian kepada masyarakat ini dilaksanakan pada bulan Mei sampai Juli 2019. Lokasi kegiatan pengabdian kepada masyarakat ini dilaksanakan di SMPN 21 Kota Pekanbaru. Sarana yang digunakan dalam kegiatan ini meliputi ruang kelas dan aula sekolah. Alat utama yang digunakan adalah laptop, infokus, alat tulis dan leaflet. Pendekatan atau meteode yang dipakai adalah pendidikan kesehatan di kelas VII, VIII dan IX, dilakukan sebanyak 4 kali kegiatan. Variabel yang diamati adalah pengetahuan siswa setelah diberikan pengetahuan tentang media sosial dan dianalisa menggunakan uji Paired Sample t-test.

\section{HASIL DAN PEMBAHASAN}

Hasil

Berikut hasil dari pre-test dan post-test tentang media sosial dan penggunaannya di SMPN 21 Pekanbaru.

Tabel 1. Hasil Pre-Test dan Post-Test Siswa-Siswi

\begin{tabular}{ccc}
\hline Variabel & Mean \pm Std. Deviation & P-Value \\
\hline Nilai Pre-test & $78,6 \pm 11$ & $0.000^{*}$
\end{tabular}




\begin{tabular}{ccc}
\hline Variabel & Mean \pm Std. Deviation & P-Value \\
\hline Nilai Pre-test & $78,6 \pm 11$ & $0.000^{*}$ \\
Nilai Post-test & $96,6 \pm 5.3$ & \\
\hline Ket $\quad$ : Ada perbedaan yang signifikan dalam uji paired sample t-test $\quad(\propto<0.05)$
\end{tabular}

Berdasarkan hasil uji Paired Sample t-test yang dilakukan pada nilai Pre dan Post, didapatkan hasil bahwa terdapat perbedaan pengetahuan antara sebelum diberikan pendidikan kesehatan dengan sesudah diberikan pendidikan kesehatan. Hal ini menunjukkan bahwa pendidikan kesehatan mempengaruhi dalam meningkatkan pengetahuan siswa remaja tentang jenis media sosial, dampak positif dan negatif media sosial pada kesehatan fisik dan mental serta kiat-kiat menghindari dampak negatif media sosial.

\section{Pembahasan}

Kegiatan peningkatan pengetahuan remaja diawali dengan kegiatan penjajakan terkait penggunaan media sosial di SMPN 21 Pekanbaru. SMP ini merupakan salah satu sekolah di Pekanbaru dengan jumlah siswa yang cukup banyak yaitu berjumlah 1129 orang. Dilihat dari lokasi sekolah, SMPN 21 berlokasi cukup strategis yaitu terletak di tempat yang ramai. Selain itu, siswa juga diperbolehkan membawa handphone ke sekolah. Mengingat pekembangan remaja adalah salah satu periode penting dalam masa perkembangannya, maka remaja sangat dapat terpengaruh dengan lingkungan dan juga media sosial yang sangat berkembang saat ini. Pengaruh media sosial ini dapat berdampak positif ataupun negatif pada kesehatan fisik dan mental para penggunanya.

Kegiatan pengabdian masyarakat ini diawali dengan memberikan pre-test sebelum menjelaskan materi tentang penggunaan media sosial, dampak positif dan negatif serta kiat-kiat untuk menghindari dampak negatif. Pre-test yang diberikan berupa 15 pertanyaan terkait dengan materi yang akan dijelaskan. Setelah penjelasan materi, para peserta diberikan post-test dengan pertanyaan yang sama dengan pre-test. Hal ini untuk melihat sejauh mana pemahaman para siswa terhadap materi yang telah dijelaskan.

Setelah itu, dilakukan pendidikan kesehatan kepada perwakilan siswa dari kelas VII, VIII dan IX. Kegiatan berlangsung 2 kali pertemuan dan diakhiri dengan post test. Materi ini disampaikan oleh tim pengabmas. Setelah itu, di pilih duta media sosial sehat dari setiap tingkat kelas yang terdiri dari 2 orang dari kelas VII, 2 orang dari kelas VIII serta 2 orang dari kelas IX. Penilaian dipilih berdasarkan hasil pengamatan terhadap sikap mereka dalam keaktifan selama proses pendidikan kesehatan dan berdasarkan nilai pre-test dan post-test yang terbaik.

Pada pertemuan berikutnya, duta media sosial akan menyampaikan materi kepada teman sebayanya di kelas. Kegiatan inilah yang menjadi inti dimana dilakukan pendidikan kesehatan dengan pendekatan peer group. Selama kegiatan ini berlangsung, para duta memaparkan materinya dan terlihat antusias dari teman-temannya. Kegiatan ini juga diadakan pre-test dan post-test untuk mengetahui tingkat pengetahuan siswa sebelum dan sesudah diberikan pendidikan kesehatan.

Berdasarkan tabel 1 dapat dilihat bahwa rata-rata nilai yang didapatkan siswa di SMPN 21 Pekanbaru yaitu pre-test 78,6 dan post-test 96,6. Hasil tersebut juga menunjukkan terdapat peningkatan pengetahuan siswa setelah diberikan pendidikan kesehatan sebesar 18,1. Hasil uji statistik didapatkan nilai $0,000(p<0,05)$ yang dapat disimpulkan ada perbedaan yang signifikan antara pre-test dan post-test yang dilakukan 
oleh para siswa di SMPN 21 Pekanbaru. Setelah dilihat dari hasil nilai pre-test dan posttest, rata-rata nilai siswa mengalami peningkatan. Sehingga dapat dikatakan pemahaman siswa tentang media sosial dan penggunaannya mengalami peningkatan setelah diberikan pendidikan kesehatan.

Pengetahuan/ kognitif adalah domain yang penting untuk terbentuknya tindakan seseorang (Notoatmodjo, 2007). Pengetahuan dapat ditingkatkan dengan proses pembelajaran berkelompok bersama teman sebaya (peer group). Menurut Mellanby (1995 dalam Rofi'ah, 2017) menyatakan bahwa pendidikan kesehatan dengan teman sebaya akan menjadikan remaja lebih mudah berkomunikasi dan terbuka dengan teman sebayanya dibandingkan dengan orang tua dan guru. Hasil penelitian oleh Nelma (2008 dalam Rofi'ah, 2017) juga menyebutkan bahwa kelompok sebaya memberikan pengaruh terhadap peningkatan pengetauan remaja.

Setelah kegiatan berakhir, tim pengabmas berharap pihak pengelola sekolah untuk terus melanjutkan kegiatan pengawasan terhadap kegiatan siswa dalam penggunan handphone beserta media sosialnya. Selain itu juga perlu membuat kegiatan untuk siswa seperti menggunakan media sosial yang dipilih dalam melengkapi tugas sekolah. Hal ini diharapkan agar membiasakan siswa memilih media sosial yang tepat dan mengetahui cara penggunaan yang benar. Sekolah juga menyadari pentingnya pengawasan dan pemberian informasi untuk siswa terkait penggunaan media sosial saat ini sehingga mendukung kegiatan pengabdian masyarakat ini.

\section{KESIMPULAN}

Berdasarkan hasil pre-test dan post-test, terjadi peningkatan pengetahuan dengan nilai rata-rata pre-test 78,6 dan post-test 96,6 . Perbedaan peningkatan nilai rata-rata yaitu sebesar 18,1. Hasil uji statistik didapatkan nilai $0,000(\mathrm{p}<0,05)$ yang dapat disimpulkan ada perbedaan yang signifikan antara pre-test dan post-test yang dilakukan oleh para siswa di SMPN 21 Pekanbaru. Pihak sekolah untuk memasukkan kegiatan peningkatan pengetahuan remaja tentang media sosial, dampak positif serta dampak negatif dari penggunaannya ke dalam jadwal ekstrakulikuler sekolah. Hal ini dapat dilakukan dalam kelompok-kelompok/ peer group bersama duta media sosial yang telah dipilih.

\section{DAFTAR PUSTAKA}

[1]. Abdul Rozak \& Wahdi Sayuti. 2006. Remaja dan Bahaya Narkoba, Jakarta. Prenada.

[2]. Afandi, M., Chamalah, E. dan Wardani, P.O.2013. Model dan Metode Pembelajaran di Sekolah. Semarang. Unissula Press

[3]. Asosiasi Penyelenggara Jasa Internet Indonesia (APJII). 2016. Penetrasi \& Perilaku Pengguna Internet Indonesia. http://www.apjii.or.id/survei [24 Desember 2018]

[4]. Atila, Cemal. 2018. Daftar Situs Jaringan Sosial. dari https://socialmedialist.org/daftar-media-sosial.html [26 Desember 2018]

[5]. Hurlock, E.B. 2011. Psikologi Perkembangan: Suatu Pendekatan Sepanjang Rentang Kehidupan. Edisi Kelima (Alih Bahasa: Istiwidayanti dan Soedjarwo) Jakarta. Erlangga.

[6]. Monk, J. F., Knoers, P. M. 2004. Psikologi Perkembangan (Pengantar Dalam Berbagai Bagianya). Yogyakarta. Gajah Mada University Press 
[7]. Notoatmodjo, Soekidjo.2010. Ilmu Perilaku Kesehatan. Jakarta. Rineka Cipta.

[8]. Nurmandia, H. Denok Wigati, dan Luluk Masluchah. 2013. Hubungan Antara Kemampuan Sosialisasi dengan Kecanduan Jejaring Sosial. Jurnal Penelitian Psikologi. Vol. 04, No. 02, 107-119

[9]. Nursalam \& Efendi. 2008. Pendidikan Dalam Keperawatan. Jakarta. Salemba Medika.

[10]. Okoiye, O. E., Anayochi, N. N., \& Onah, A. T. 2015. Moderating effect of cyber bullying on the psychological well-being of in-school adolescents in benin edo state nigeria. European Journal of Sustainable Development, 4(1), 109-118. Retrieved from http://search.proquest.com/docview/1669904821?accountid=48290

[11]. Papalia, Olds \& Feldman. 2011. Human Development (11thed.) New York. The McGraw-Hill Companies,Inc

[12]. Purbono, Imam Arif. 2015. Tingkat Pengetahuan Remaja tentang Kesehatan Reproduksi. Vol 1 No2 Jurnal FamilyEdu

[13]. Santrock, J. W. (2008). Educational Psychology. 3rd edition. New York. McGraw-Hill Companies.

[14]. Sari, Tesha H.,Siswadi, Sriati. 2018. Use of Social Media with Self-Concept and Social Adjustment of Adolescents at SMPN 2 Singingi Hilir Riau. Asia Pacific Journal of Multidisciplinary Research. Vol.6 No.2, 45-52. P-ISSN 2350-7756.EISSN 2350-8442

[15]. Steinberg, Laurence. 2011. Adolescence. 6th ed. New York : Mc Graw- Hill

[16]. Tartari, E. (2015). Benefits And Risks Of Children And Adolescents Using Social

Media. European Scientific Journal, 11(13) Retrieved from http://search.proquest.com/docview/1702667551?accountid=48290.

[17]. Triwibowo, C dan Pusphandani, ME. 2015. Pengantar Dasar Ilmu Kesehatan Masyarakat. Yogyakarta. Nuha Medika

[18]. Wawan dan Dewi M. 2009. Teori \& Pengukuiran Pengetahuan, Sikap, dan Perilaku

Manusia. Nuha Medika. Yogyakarta

[19]. We Are Social. (2015). Digital In 2015. Diakses pada tanggal 27 Desember 2018 https://wearesocial.com/special-reports/digital-in-2015

[20]. Widyastuti, Dkk. 2009. Kesehatan Reproduksi.Yogyakarta. Fitramaya.

[21]. Wijaya, Chandra., \& Godwin, Raymond. (2012). Hubungan perilaku sosial dalam beraktivitas di situs jejaring sosial dan dunia nyata pada remaja di Jakarta. Jurnal Universtas Bina Nusantara. 